研究発表論文

\title{
施策公園の展開に関する台日比較
}

\section{The Comparison of Policy Park Development between Taiwan and Japan}

\author{
楊＼cjkstart蓓涵 ${ }^{*}$ 金子 忠一** 㝨茂寿太郎** \\ Peihan YANG Tadakazu KANEKO Toshitaro MINOMO
}

\begin{abstract}
For the post-war tactic, R.O.C. government had given priority to the policy of economical development since 1945. Then, due to the development of leisure concept and the raising concern of environment, R.O.C. government has adopted "Policy Park" since mid-1970. There are 4 domains will be studied in this thesis, which include : (1) analyze the development and transformation of Taiwan Policy Park, which is based on the concept of Japanese Policy Park. (2) systematize the Policy Park through the studies of its set-up background that relates to the social trends such as politics, economics and citizen request (3) compare the Policy Park between Taiwan and Japan to discuss their similar and different points (4) analyze the relativity of Policy Park implemented in Taiwan and Japan through the studies of national income.
\end{abstract}

Keywords: Taiwan, Urban Park, Policy Park, Park development, Park Policy キーワード：台湾, 都市公園, 施策公園, 公園整備, 公園政策

\section{1. 研究の背景と目的, 方法と前提}

\section{(1) 研究の背景と目的}

台湾における都市公園政策は, 日本植民地時代に始まり，台湾 総督府の律令や台湾都市計画令などにより公園地に関する規定が 定められたことを起源としている。終戦後むそれらを暫く援用し， 独自の公園施策を追加して公園整備は続けてきた。

本研究のキーワードである施策公園は, 純粋な計画論に基づく 公園種別, 即ち街区公園や近隣公園などと違い, 事業論に基づい て命名される公園種別の包括概念で，日本において昭和 51 （1976）年頃から用いられた用語である。つまり，国民の都市公 園に対する多様なニーズに対応し, 数ある公園機能の中から特定 のものに着目し, 重点的な公園整備を効果的に行うという発想か ら考えられたものである。この施策公園という行政用語は台湾に はなく, 従って施策公園に関する研究むない。本研究では日本の 施策公園の概念を基に, 1945 年以降の台湾に打ける公園整備之 社会動向とを相対させることで，表題の比較を試みたものである。 つまり, 台湾に打ける多様な公園の成立背景を社会的ニーズから 体系的に考察する一方で, それに相当する日本の施策公園を対置 させ, 両国の施策公園の共通点之相違点を解明することを目的と した。

\section{(2) 研究の方法}

本研究は, 文献調查に基づき, 台湾の公園政策にみられる公園 種別の調査を行い, 施策公園に相当する公園を抽出し, その代表 例を取り上げた。またそうした公園誕生をとりまく環境の変貌を 整理し, 施策公園の時代的变遷としてみた。最後に日本の施策公 園が策定された時期との違いを比較し, 時代の潮流に応じた公園 の誕生の背景を解明した。

\section{(3) 研究の前提}

日本の都市公園行政において, 施策公園の展開は以下の通りで ある。日本の公園制度は, 明治 6 (1873) 年の太政官布達第 16 号をもって始まったが，昭和 31 （1956）年の都市公園法の制定
により, 初めて都市公園の整備と管理の法的な定義が明確にされ, 公園の整備水準，配置標準，管理基準等が定められた。

昭和 30 年代になり, 児童の交通事故の激増により, その安全 対策として児童公園に加え, 交通公園の整備が都市公園整備の最 重点施策として取り上げられた。そして都市環境の改善，公害対 策上等の視点から昭和 40 (1965) 年に河川敷緑地整備事業, 昭 和 43 （1968）年に緩衝緑地事業が制度化された。また昭和 43 （1968）年に国営武蔵丘陵森林公園の整備が着手され，昭和 44 （1969）年にはレクリエーション都市整備の施策が試みられた。 そして昭和 47 (1972) 年から, 国の長期計画の一つとして都市 公園等整備五箇年計画（表一 1 ）が始まり，その整備目標は，社 会的ニーズに応じた目標に向かった。昭和 52（1977）年以降は, 緑のマスタープランの策定により都市の総合的な公園緑地政策が 推進されることとなった。昭和 55（1980）年には農山漁村地域 の生活環境を改善するためのカントリーパークの整備, また昭和 61（1986）年には防災緑地緊急整備事業が創設された。

このように計画面の体制が整備された他，昭和 50 (1975）年 以降になると, より特徵ある施策が展開されてきたと言える。昭 和 51 （1976）年に都市住民の都市緑化意識の高揚，植栽知識の 普及等を図るための都市緑化植物園, 昭和 53 （1978）年には震 災時に防災拠点, 避難地, 避難路となる防災公園, 昭和 54 （1979）年に地域の文化・スポーツ等の活動拠点となるカルチャー パーク，昭和 56（1981）年に都市景観の向上・都市環境の改善 等を目的とする広場公園及びタウンスクエア，遊休となっている 私的空間地を活用した公開緑地，昭和 57 （1982）年に市街化区 域内農地を借地し, 土・自然に親しむ機会を提供する分区園緑地 （タウンズファーム）等の施策が次々と創設された。

昭和 60 （1985）年には高齢化社会に対応し，高齢者之子供が 共に楽しめるふれあい公園及び地域住民の郷土文化に対する意識 の高揚と地場産業の振興を図るクラフトパーク，昭和 62 (1987) 年に日常的な運動ができる施設や健康運動相談所むある健康運動

*東京農業大学大学院農学研究科 ${ }^{* *}$ 東京農業大学地域環境科学部造園科学科 


\section{表－1＼cjkstart都市公園等整備五箇年計画と日本の施策公園}

\begin{tabular}{|c|c|c|c|}
\hline 都市公園 & 等整備五箇年 & F計画 & 整備の対象となった公園の種別 \\
\hline 第1次 & $1972(\mathrm{~S} 47)$ & 年 & 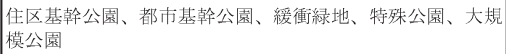 \\
\hline 第2次 & $1976(\mathrm{~S} 51)$ & 年 & $\begin{array}{l}\text { 住区基幹公園、都市基幹公園、特殊公園、大絸模公園、緩 } \\
\text { 都市緑地、緑道、国営公園 }\end{array}$ \\
\hline 第3次 & $1981(\mathrm{~S} 56)$ & 年 & 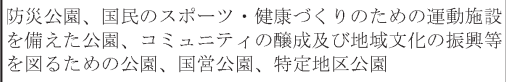 \\
\hline 第4次 & $1986(\mathrm{~S} 61)$ & 年 & $\begin{array}{l}\text { 防災公園、国民の健康の維持增進に資する公園、㕕域的レ } \\
\text { クリエジン需要に刘灾する公園、国民多様なニース } \\
\text { に対応する公園 }\end{array}$ \\
\hline 第5次 & 1991 (H 3) & 年 & 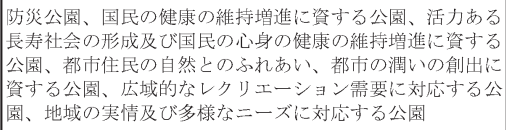 \\
\hline $\begin{array}{c}\text { 第6次都市” } \\
\text { 画 }\end{array}$ & $\begin{array}{l}\text { 公園等整備七 } \\
1996 \text { (H8) 年 }\end{array}$ & 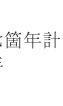 & 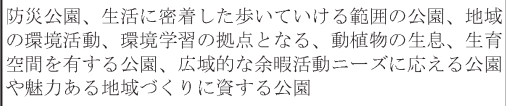 \\
\hline
\end{tabular}

公園などの整備を目的とした健康・運動公園整備事業, 国民の多 様な野外活動に対応したオートキャンプ場など2), 社会のニーズ に対応する施策が見られるようになった。

平成 2 （1990）年に地域特性を活かし，特定テーマを有した， 地域活性化に資する地域活性化拠点公園整備事業, 平成 4 （1992）年に廃棄物処分場跡地等を活用した公園及びゴミ焼却場 の廃熱等を活用した建設副産物等の有効活用に資する公園, 平成 6 （1994）年に生産緑地の有効活用を図るとともに，家族が共に 土とふれあうことのできる市民農園整備事業, 平成 7 (1995) 年 に市街地の安全性を特に確保すべき地域における, 低・未利用地 の買収と多様な緑地の整備としたグリーンオアシス緊急整備事業, 平成 8 （1996）年に市民の環境活動や指導者育成等の拠点として 自然生態園や野鳥観察所等の施設を整備する環境ふれあい公園, 平成 9 （1997）年に水々緑の復元による快適な都市環境の形成, 多様な動植物の生息地の確保を図る水と緑のネットワーク公園整 備事業, また身近な歴史風土や地域の特徵となる景観を地域と一 体となって保存, 復元, 体験する地域ルネッサンス公園等 ${ }^{3)}$, 多 種多様の公園施策が実施されている。バブル経済の崩壊から地域 活性化に資する対応, 及び輻輳化した環境問題への対応など, 公 園施策は大きく変わりつつある。

\section{2. 台湾における都市公園整備の展開}

一方，台湾では，1899 年 11 月に台湾総督府により律令第 30 号が発効し, 市区計画に㧍ける公園予定地の規制の道が開かれ た ${ }^{4)}$ 。1936 年 8 月に律令第 2 号の台湾都市計画令, 同年 12 月に は同令施行規則が公布された。1937 年 8 月, 台湾では都市計画 講習録 ${ }^{5)}$ が刊行され，これが都市計画の実務上の指導書となって いる。その中に, 台湾の公園の種類に関する計画指針が規定され ており, 公園の種類, 面積標準, 誘致距離は, 日本の計画標準に 従っている。

1945 年の終戦後 1964 年までの期間, 中央政府は日本植民地時 代の台湾都市計画令を引き続き援用した。1964 年 9 月になって, 独自の都市計画法として全面改正されたことで, 公園, 緑地, 広 場, 児童遊び場の面積が規定された。1975 年 5 月に内政部は 「都市計画定期通盤検討実施辦法」 ${ }^{6}$ を作り, 児童遊び場や公園緑 地などの施設用地の最小面積基準を定めた。さらに，1996 年の 営建政策白皮書 $(\text { 白書 })^{7)}$ により, 公園種別が規定された。表一 2 は 1937 年, 1975 年, 1996 年の 3 つの時期に策定された台湾に おける公園緑地の種別を表したものである。

1949 年には国民党之共産党の内戦により中央政府は台湾に撤 退した。1953 年から 4 年期間の四力年経済計画が国家的事業之
してスタートした。これにより 輸出振興, 経済成長, 工業化等 に力を入れた結果, 1962 年に ようやく工業生産高が農業生産 高を上回るようになった ${ }^{8)}$ 。こ の結果, 農村から都市への人口 の流入は, 都市のスプロール化 などの都市問題をもたらした。 このため 1970 年代になり, 政 府は続々と公園施策を展開した。 な打本研究では，考察の対象を 台湾の直轄市である台北市と高 雄市, 宜蘭県を中心とした。

\section{3. 台湾における公園の展開と 日本の施策公園との対置}

（1）青少年問題の解決策とな る青年公園

1949 年に台北市は中華民国 の臨時的な首都となったが，そ
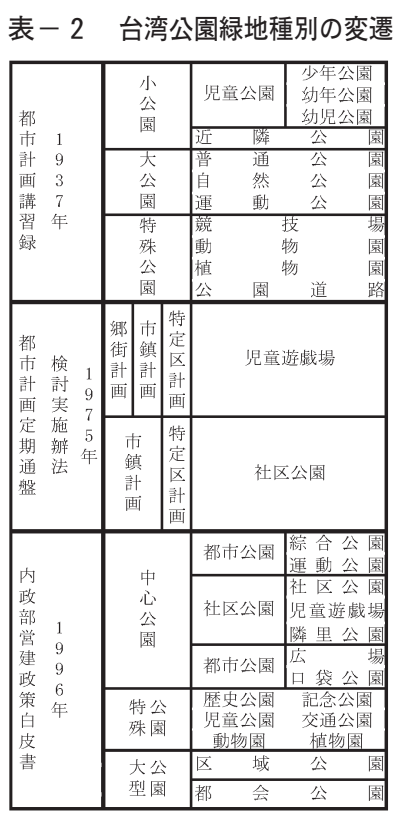
の後工業化の推進に伴う都市化により, 人口の一極集中現象が進 んだ。1949 年の台北市の人口は 48 万人だったが, 25 年後の 1974 年には 200 万人にのぼっている。この間に台北市において

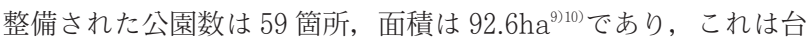
北市域面積の $0.34 \%$, 人口一人当たりの公園面積は $0.46 \mathrm{~m}^{2}$ の水 準である。しかし, 整備された公園はほとんどが日本の近隣公園 に相当する隣里公園であり， 5 ha 以上の規模の公園は， 3 箇所 （天母公園 5.8ha, 双渓公園 6.2ha 及び中山公園 11ha）のみであ る。

都市化による人口の急増は, 都市に抢けるレクリエーション地 の不足及び青少年問題を起こした ${ }^{11)} 。 1974$ 年 3 月に行政院はそ うした社会問題に着目し，青少年の利用を想定した公園の整備を 台北市政府に指示した ${ }^{12)}$ 。この公園は，青年公園と命名され，面 積 24.44ha, ゴルフ練習場, プール，テニスコート，バスケット ボール場，野球場，スケート場等の施設がある公園として 1977 年 9 月に整備された。

青年公園の成立背景は青少年問題がきっかけであったが，青少 年のみならず，台北市民を対象に総合的なレクリエーションの場 に供する総合公園である。このことは, 当時の都市内におけるレ クリエーション空間, つまり都市公園の不足問題む背景に考えら れる。

日本の公園体系では，休惒，観賞，散歩，遊戯，運動等の総合 的な利用に供する公園は総合公園であることから，台湾の青年公 園は, 公園の設置目的, 施設, 創設当時の台北市における状況か ら，日本の総合公園に相当すると言える。

\section{（2）水への親しみを高めた親水公園}

1980 年代に入ると, 行政院は観光事業を推進するため, レク リエーション地区の開発を中央政府施策の重点とするよう指示し た ${ }^{13)}$ 。

1982 年に宜蘭県政府は, 冬山河整備基本計画に基づき, 河川 主流の $10 \mathrm{~km}$ 改修した。1984 年 10 月には冬山河風景区開発計画 を一環とする宜蘭県観光発展全体計画を定めた。さらに 1986 年 には冬山河風景区開発計画を行政院の重要経済建設投資計画の中 に位置付けることとなった ${ }^{14)}$ 。

日本の設計コンサルタントが携わったこの冬山河風景区開発計 画は, 計画面積 450ha（水域面積 108ha), 上流に森林公園, 中 流に親水公園，下流に海浜公園が計画され，河川において水と親 しめる公園づくりの施策が台湾で初めて登場した。冬山河親水公 
園は 1994 年に完成し, 公園に㧍ける防洪, 防災, 観賞, さらに 風景地区としての利用等様々な機能を持つことが知られるように なり, 公園への親しみやすさを生じさせ, 台湾の人々に公園に対 する伝統的な印象を大きく変えることとなった。この親水公園は 台湾に扔ける公園の利用形態に多大な影響を与え, 当時最も人気 のある「観光スポット」となり, その後, 各都市で続々と親水公 園が整備され始めた。

日本では，公園利用者が水に直接触れられることを第一の目的 として，全域を池や流れに特化した設計がされた親水公園は, 1973 年に完成した古川親水公園が最初である。古川親水公園は 下水道整備, 冬山河親水公園は河川改修之共に整備されたもので あるが，いずれも水と親しめる河川整備を目的とした点が共通し ている。

\section{（3）各郷鎮（市町村）に広がった運動公園}

台湾には，1980 年代以前に体育場はあったが，運動公園は無 かった。1985 年, 台湾全国中学校運動会が宜蘭県で開催される ことをきっかけとして, 1983 年に県政府は体育, 造園, 都市の プランナーらを招き, 体育場の形態をなす宜蘭運動公園（面積 8 ha）に緑地空間を設け, 面積 27ha の公園に拡大することを決定 した ${ }^{15)}$ 。この公園は台湾において運動公園の先導となり, 1996 年 3 月には宜蘭県羅東鎮に羅東運動公園（計画面積 46.8ha）が 開園され, 有名観光地の一つにもなり, 後の運動公園の普及に拍 車をかけた。

宜蘭県のこの 2 つ運動公園施策は, 中央政府に影響を及ぼす ことになり，1988 年に国家体育建設中程計画が行政院にて閣議 され, 運動公園の整備が計画された。しかし, 用地取得の困難に よって，整備はなかなか進まなかった ${ }^{16)}$ 。1991 年に行政院によっ て策定された国家建設 6 力年計画の中に, 各市町村において運動 公園を整備する旨が明記された勇。これは公園緑地整備を取り入 れた初の国家的事業となり, 運動公園が全国各地で整備されるよ うになった。

日本の運動公園は, 1964 年に行われた東京オリンピック大会の 第 2 会場として建設された駒沢オリンピック公園が, 最む代表的 なものと言える。また 1972 年から第一次都市公園等整備 5 箇年 計画などと相まって, 国民体育大会会場が運動公園として整備さ れるようになった ${ }^{18)}$ が，1946 年の第 1 回国体の開催地の 1 つで ある西京極運動公園（京都市運動場）は 1930 年に着工，1942 年 に完成している。

台湾の運動公園は, 都市住民の日常生活に運動の場を提供する ことを目的としており，日本の運動公園に相当すると言える。台 湾の運動公園は, 「運動公園規劃準則」19)によって, 市街地では 3 ha 以上, 市街地周辺部では 5 ha 以上, 郊外では 10 ha 以上と規 定されている。それに対し, 日本の運動公園は, 都市規模に応じ 1 箇所当り 15～75ha を標準としており，運動公園の規模の違い が見られる。

\section{（4）広域レベルの都会公園}

台湾は工業化により, 人口が都市に集中し, 1985 年の時点で 台北市, 台中市及び高雄市の 3 大都市の人口の占める割合は全体 の 44\%に達した。

1988 年 5 月に行政院は, 都市民にレクリエーションの場を提 供するため, 「台湾地区都会区域休閑設施発展方案」を策定し ${ }^{200}$, それに基づいて, 内政部営建署は都会公園の設置研究を推進し始 めた。1993 年にその施策は「十二項目重点建設計画」 ${ }^{21)}$ に位置づ けられ, 国家建設の 1 項目となった。都会公園は国の直轄事業で あり, 内政部営建署が担当部署となっている。

台湾は国民所得が増加し, 週休二日制の実施により, 国民の旅 行も盛んになり，レジャ一的要素も含んだ都市民の週末利用のレ クリエーション需要に十分に対応できていなかった。そうした中
で，都会公園は，都市住民の利用に供するだけでなく，遠方地域 からの旅行者のレクリエーション需要に応じた都市公園としても 新たな展開となった。

台湾で最初の都会公園は高雄都会公園（計画面積 95ha）であ り，1989 年に行政院により計画案が策定され，1996 年に部分開 園しており，第 2 期整備事業は 2005 年完成予定である。台中都 会公園（計画面積 88ha）は，1992 年に行政院により計画され, 2000 年に開園した。また, 第三の台南都会公園は敷地決定され たが，まだ整備はされていない。

都会公園は国が設置する大規模な公園であり, 日本の国営公園 （1968 年）に相当する。しかし, 計画標準に違いがみられ, 国営 公園は 1 力所当り面積概称 $300 \mathrm{ha}$ 以上としているのに対し, 台 湾の都会公園は 100 ha 以上としている。

\section{（5）市民参加を取り入れた公園づくり}

1987 年に開園した花蓮市美崙山公園は，協議会方式により， 住民の意見を聞いて整備されており，台湾において市民参加の概 念を取り入れた最初の公園づくりと位置づけられる222。しかし， 本格的に市民参加を取り入れた公園づくりと言えるのは, 1992 年に台北県三重市の後竹囲公園の再整備にあたり, 台湾大学がワー キング・グループを結成し，周辺住民に参加を呼びかけたことが 初めてである。また同年, 台北県政府は台湾, 淡江, 華梵, 中原, 輔仁, 文化の 6 つ大学に市民参加による近隣公園の設計を委託し ている ${ }^{23)}$ 。

1996 年，台北市政府紀要に扔いて公園の計画設計は地域に求 められるニーズに合わせ，利用者優先の原則で整備することが明 記され, 計画設計の際には, 地元の民意代表 (市議員), 区長, 里長 (町長) と住民に説明会を開く事が義務づけられた ${ }^{24)}$ 。

このような台湾の市民参加を取り入れた公園づくりは，1980 年代の政治民主化及び社会運動の発展過程において徐々に現れて きたものであった。1987 年に戒厳令は解除され, 社会運動の台 頭によって市民意識が高揚し, 市民からの環境改善の訴えも出て きた。そこで公園整備に参加することによって，市民が公共事業 の領域に直接触れ, 市民の要望で政府に執行させることを望んだ。 昔のような消極的, 受動的立場ではなく, 住民の意思によって積 極的に公園の設計または整備に参加することに意味があり，これ は民主化が進んだ表れであると考えられる。

台湾の市民参加を取り入れた公園づくりは，学術界などの有識 者により先導されたあのであるが，現在では「台北市政府各機関 可開放市民参與業務実施方案」25)により公共事務及び施設に対し, 計画から施工の全段階で諮問グループを設置することができると 規定し，住民又は市民代表などを委員として起用し，計画及び設 計，施工の監督，工事の完了検査などに参画できると定めている。 日本では, ワークショップ方式の公園づくりが, 1982 年頃から 本格的に取り入れるようになった ${ }^{26)}$ 。その魁は, 住民グループの 草の根的まちづくりにおける小公園の改修などに端を発したもの で，初期に扔いて，行政は受身的であったことを否めないが，次 第に先鋭的な限られた自治体に执いて担当する行政技術者の努力 と, これに共感するコンサルタント技術者の協力があって醇成し, 今日では, 普段の行政として多くの自治体でなされるまでになっ た。

\section{（6）都市に導入された森林公園}

台北市の大安森林公園は，日本植民地時代の 1932 年 3 月 7 日 に台北州告示第 54 号として計画された大台北市区計画の 7 号計 画公園の一つである ${ }^{27)}$ 。1974 年, 行政院から 7 号公園の整備を 台北市政府は指示され，1985 年に第一次計画案を検討，セント ラルパークとして計画したが，スポーッ界関係者から大型体育館 の建設の要望が出された。翌年，教育部は協調会を開き，公園予 定地内に直径 $120 \mathrm{~m}, 3$ 万人収容規模のドームの建設を決議する 
が環境保護団体に強烈な反対を受けた。その後長い間に渡り, ス ポーッ界と環境保護団体の激しい論争が続いた。論争は長引き, 日を追うごとに環境保護団体の行動に加わる市民が増加する結果 となった。1988 年 3 月に台北市政府は，市民の声を鑑み，第 505 次市政会議にて, 7 号公園予定地を森林公園の形態で整備するこ とを決議し ${ }^{28)} ， 1994$ 年 3 月に面積 25.894ha の森林公園を開園 した。

台北市政府は 1974 年の青年公園の整備から 1994 年の森林公園 の開園までに, 373 箇所, 総面積 784.9ha の公園を整備してきた が29)，0.5ha 未満の公園が 264 箇所で全体の $71 \%$ を占めていた。 数多くの小公園は整備されたが, 都市内に㧈いて緑による環境保 全の効用を果たすには十分に対応できていなかったと言える。森 林公園は, 台湾の都市において樹木を主体とする初めての公園で あり, コンクリートジャングルの中に緑の増量む目的とした施策 であった。また, 体育館案に対しての論争を経て, 森林公園とし て決定されたことから，市民が身近の環境問題を意識し始めたと 屯読み取れる。これは市民の緑に対する要望と環境保護の潮流に 応えた結果であある。このように, 大安森林公園が整備された要 因は, 都市に抢ける緑の量の不足及び都市住民の都市環境問題へ の反省によるものであった。

日本では, 明治百年記念森林公園が, 森林公園と命名した都市 公園を本格的に都市内に整備を広めるきっかけとなった一つとい える。昭和 41 (1966) 年, 内閣に明治百年記念準備会議が設置 され, その第 3 回会議に抢いて「明治百年記念事業項目」を決定 し, その一つとして「国及び地方公共団体は, 大都市に記念森林 公園, 郊外に明治の森の建設整備を促進する」ことが定められた。 台湾及び日本は共通して, 緑の少ない都市の内部に大規模な森を 導入し, 自然を失いつつある都市の住民が緑を通じて人間性を復 活する場を確保するため，森林公園を整備したのである。しかし， 日本の場合は，一つの記念とし森林公園を造営する性格であるの に対し, 台湾の場合は記念事業ではなく灰色の市街地に緑の森を 創る性格である。

\section{（7）モータリゼーションによる交通公園}

台湾は経済成長につれ自動車数が増加し，1988 年末の人口 100 人当たり 10.4 台の保有車数となった ${ }^{30)}$ 。1986 年に台北市政府は 交通問題の深刻化を解決するため, 交通施設の改善と共に交通教 育にも着手しょうとした。その一つとして, 子どあたちが遊びを と打して, 交通知識や交通道徳を学習し身につける目的で交通公 園を整備することが考えられた。

交通公園は面積 4 ha, 1932 年 3 月に大台北市区計画の 8 号公 園予定地の一部として計画されたものである。1988 年 7 月に台 北市長は, 工務局が携わっていた交通公園の整備事業を教育局に 移転, 児童館之合併し交通博物館の設立を決定した ${ }^{31}$ 。交通博物 館は 1991 年 8 月に開館し, 交通公園は翌年 9 月に開園した。

交通公園は, 台湾社会経済の急速な発展の中, 車輛の増加に伴 う交通事故の増加によって整備された施策公園である。交通公園 は, 都市社会の交通実情屯反映され, 児童のための交通教育の場 として整備された。

日本の交通公園は, 都市に打ける自動車の急増と児童の交通事 故の増加という社会問題を背景に, 1962 年に建設省 (現国土交 通省）通達「交通公園設置運営要項」によって定められたもので ある。当時の日本は車一台当り 55.3 人 $^{32}$ の自動車普及率であっ たのに対し, 台湾で交通公園が整備された 1992 年の自動車普及 率は車一台当り 5.2 人济で であり, 日本では早い段階で整備が進め られたことが伺える。台湾の交通公園の成立目的は, 日本の交通 公園とほぼ一致しているが, 交通公園の設置基準に関する規定は ない。

\section{（8）地域活性化が図られた社区総体営造}

1987 年に戒厳令が解除されたことにより, 政治の民主化及び 社会運動が発展した。これに伴い, 地域まちづくりの推進に重点 が移され，コミュニティ意識が芽生えた。伝統的な産業及び地方 の活力が年々衰退し，地方に扔ける文化の特性及び歴史的遺産が 失わ机るようになった。このため市町村における調和ある文化の 発展之地域らしさが社会文化政策上重要な課題となった。

「社区総体営造」は, 1994 年 10 月に行政院文化建設委員会に よって策定されたもので，その目的に「産業文化化，文化産業化」， 「文化空間及び重要公共建設の整合」などを挙げている。これは 文化事業の発展から始まり, 住民に地域の環境に愛着心を持たせ, 地域の活性化, コミュニティのアイデンティティの確立及び地域 振興に関わる公園施策である。

1994 年に社区総体営造は行政院十二項目建設計画の中に位置 づけられた ${ }^{34)}$ 。その後, 各省庁も続々と類似の政策を策定し, 社 区総体営造の関係計画により再整備された公園が全国各地で展開 するようになった。

このような地域の環境改善, 地域らしさを引き出すまちづくり を行うこととした施策は, 地方独特の文化, 経済・住民の生活形 態などを考慮し，まちのアイデンティティを高め，地域の活性化 を目的として扔り，日本のカルチャーパークに相当すると考えら れる。

\section{（9）画一の公園デザインを打破する主題公園}

1994 年に高雄市政府及び高雄市建築師公会主催の「緑化港都・ 美化高雄検討会」が開催され ${ }^{35)}$, 市内の公園は特色がなく同一化 されていることが指摘された。高雄市政府はそれに応じて, 市区 緑美化計画を提議し，主題公園の整備を策定した。

主題公園とは, 画一の公園デザインを打破し, 特色のある公園 として整備するあのである。公園にそれぞれテーマを持たせるこ とによって, 人々に多くの選択肢を与えることが出来ると考えら れた。

同年，台北市政府も主題公園の整備を着手した ${ }^{36)}$ 。周辺地域の 環境を配慮し，地域特性を活かした特定のテーマを有する公園を 整備方針とした。また大規模公園もその属性と敷地条件によって 主題公園として再整備することが決定された。

親水公園及び市民参加公園の反響を受けて，地方政府はさらに 都市を全般的に考慮した上で, 地域の特性を活かし, 地域住民の ニーズに対応する, 特色のある公園を整備または再整備すること となった。設計の多様化により，公園にそれぞれの地域の特色を 持たせることによって, 地域のシンボルとすることあ図られた。 要するに, 公園の量が増加した後, 公園の質の問題を意識し始め た施策である。

日本では, 1990 年に地域活性化拠点公園整備事業の施策を策 定している。台湾の主題公園は, 地場産業等の地域の特性を活か した特定のテーマのもとに, 都市公園を中核に地域活性化に資す る公園整備を目的としており, 日本の地域活性化拠点公園整備事 業に相当すると言える。

\section{（10）空気質浄化対策としての環境保護公園}

台湾は経済的輸出指向の政策を図り, 工業の発展を一途に辿っ てきたが, 環境負荷は日々悪化し, 工場周辺の空気污染, 水質の 悪化, また車やバイクの増加による大量の排気ガスなどの環境污 染問題が次々と発生した。そこで政府は 1975 年 5 月に空気污染 防止法を公布し, 污染源の管制, 空気質の保護, 国民健康の保障 など初めて空気污染防止に関する法的な基礎ができた。

1982 年に衛生署環境保護局が創設され，1987 年に環境保護署 に昇格した。1995 年 5 月に環境保護署は「空気污染防制費収費 辦法」を公布した。この法律に基づく, バイクや車などのガソリ ン税から徵収した空気污染防止費の一部を, 全国各地の環境保護 公園（また空気質浄化地区）整備の補助金として使い，空気質を 
改善することを目的としている ${ }^{37)}$ 。

環境保護公園は環境保護，環境教育を目的とし，それに関する 研究開発などを行う機能を持つ公園緑地とされている。公園の植 栽は「一般環保公園設計準則」38) に定められている。その内容は, 空気污染を浄化する機能を持つ樹種の使用を原則に掲げ，その準 則では, 台湾全土 (84 種), 北部 (12 種), 中部 (22 種), 南部 (22 種), 海浜地区 (41 種), 高污染地区（47 種）に適応する樹種, 及び高污染地区に不適応な樹種（10 種）などを指定している。 しかし，1997 年 6 月に公園用地の権原の確認及び取得が困難な ことを理由として施策は中止となり, その経費を街路樹整備など に支出することになった。また環境保護公園による空気浄化の効 果は, 一時的に見えるものではないため, 効果が疑われ中止になっ たとも言わ机ている。

台湾の環境保護公園は, 廃棄物処分場跡地の再整備, ゴミ焼却 場から出た廃熱等の利用も整備内容の 1 つに含まれている。この 点では, 1992 年に日本の建設副産物等の有効活用に資する公園 に相当すると考えられる。

また, 環境保護公園は, 空気浄化機能を持つ植栽の指定を特徵 とする独特な公園施策であり, 公害発生のおそれがある工場群と 隣接する住居地域等とを分離, 遮断することを目的に設けられた 日本の緩衝緑地（1972 年）とは，異なる性格のむのと言える。

\section{（11）大地震の教訓による防災公園}

1996 年に内政部営建署が主催する初の「全国公園緑地会議」 が開催され ${ }^{399}$, 公園緑地の範囲之定義が明確化し, 公園緑地整備 に関する執行方案及び政策の制定が決定されることになった。そ の内容は営建政策白皮書（1996 年）に位置づけられている。さ らに, 内政部営建署は 1997 年に「公園緑地法草案」を制定し, 公園緑地が持つ景観美, 生態系, レクリエーション, 防災避難の 四大機能の構築を目標之した都市公園の整備が考案された。しか し, 防災公園の整備については執行されて抢らず，防災公園の定 義や具体的な規定は制定されていなかった。

1999 年 9 月 21 日に台湾中部で起こったM7.6 の大地震は, 戦 後初の大被害をむたらし, 政府は積極的に緑地防災システムの構 築を始めた。大地震の翌年に台北市政府は, 防災公園の制度がま だ不十分な状況下，市内の 12 の行政区域に 12 ヶ所の防災公園を 指定し ${ }^{40)}$, 公園内には消防器材, 医療用品などの備蓄庫を整備し ている。

このように大地震の教訓が, 緑地の防災上の役割に対する人々 の認識を一気に高めるきっかけとなり, 本格的に公園の防災機能 が検討され，防災公園が整備されるようになった。

台湾は, 戦後から 1998 年まで地震による大きな災害がなかっ たことから，防災公園の必要性は認識されていなかった。しかし， 1999 年の集集大地震で大きな被害を受け, また日本の阪神淡路 大震災の教訓をふまえて, 台湾各都市に防災公園の整備が進めら れてきている。日本の防災公園整備事業は 1978 年に創設され, 地震が頻繁に起きる教訓等を踏まえ, 防災拠点, 避難地, 避難路 などを設置によって, 安全で安心できる緑豊かな都市づくりの推進 を図ろうとしたものである。

\section{4. 考察}

台湾と日本の施策公園を 比較研究した結果は, 以下 のように整理できる。日本 では, 公園種別に応じた計 画・設計の標準が都市公園 法に規定されているが，施 策公園については，法文上 にはその規定がなく，旧建
設省（現，国土交通省）の設計指針が存在するのみである。台湾 の施策公園の設計指針は，施策公園別に教育部，営建署，環境保 護署及び地方政府などに散在している。台湾と日本の違いを解明 するために，施策公園が策定された当時の両国の国民所 得 11 (12) 433 44 45) を分析した結果は, 図一1 の上うになった。さらに, 施策公園誕生の年代を対置した結果，表一 3 になり，台湾の施策 公園は, その殆どが日本より遅れて整備されているが，年代差は 次第に縮まってきていることが明らかになった。中でも，防災公 園は地震の発生が主因であり, 1999 年の集集大地震を背景に整 備されるようになったわけで, 他の施策公園とは様相を異にして いる。

また，台湾において出版されている造園関連専門誌をレビュー し，外国の公園緑地事例を取り上げて紹介した記事を抽出した結 果, 表一 4 のようになり, 外国の近年の先駆的事例を参考に公園 整備が進められてきたと考えられる。この中では近隣国である日 本の事例紹介が最も多かった。

一般的には，国民所得が高くなることにつれ，国民の公園や緑 に対する意識は変化し，それに応ずるように，様々なタイプの公 園施策が展開されたと言え，具体的に以下のように考察できた。

\section{（1）公園量の拡充要求の時期（国民所得 3000 ドル以下期）}

日本では，1956 年の都市公園法，さらに 1972 年の都市公園等 整備緊急措置法の制定により, 住区基幹公園, 都市基幹公園等の 整備が推進された。交通公園はその設置運営要領が定められ，ま た森林公園は明治百年記念事業が一つの契機のとなり整備される ようになった。都市公園法が公布直後の 1960 年には国民所得が 382 ドルであり，4511箇所の公園があったが，10 年後の 1970 年 には国民所得が 1590 ドルに達し, 公園数が 13115 箇所に整備さ れている。

台湾は終戦後，社会情勢の乱れを整頓し，経済優先政策を執行 してきた。台北市は隣里公園を整備し続けてきたが，ようやく 1974 年に台湾に扔いて初の施策公園となる青年公園が整備され るようになった。

都市化が急速に進むにつれ，人口が都市に集中し，都市民のレ クリエーション，運動する空間の不足が顕著となり，公園緑地の 量を増やすことが施策の重点となった。

（2）公園の利用形態の変化時期（国民所得 1000-10000 ドル期）

日本ではこの時期に, 国営公園, 親水公園, カルチャーパーク, ワークショップ方式公園づくりなどの施策を策定し, 台湾は, 運 動公園, 親水公園, 森林公園, 都会公園, 市民参加を取り入れた 公園などの施策公園を策定した。

この時期において，都市基幹公園等は整備されつつあるが，国 民所得の増大により, 都市のスプロール化が進み, 人口が一極集 中したため, 大都市の住民の多様なレクリエーションのニーズに 応え, 大規模公園が整備されるようになった。国民所得と共に, 公園緑地の量も増加したことで, 市民の公園緑地の利用形態の変 化に対する要請が表れ，親水公園のような公園が誕生した。さら に，教育の普及及び情報化により，市民の公共への意識が高まり， 


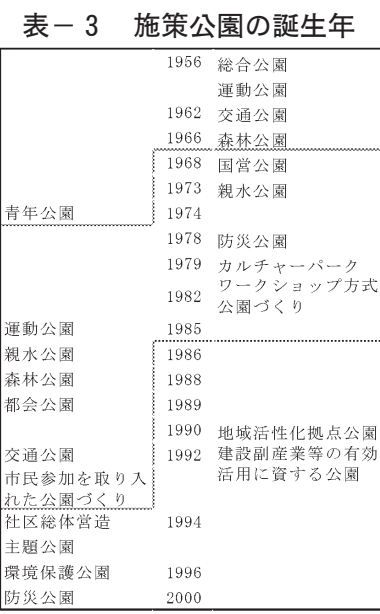

公共事業への参加が活発化する ようになった。公園づくりも行 政主導型加ら市民参加型へ転換 していった。

日本はこの時期には，すでに 質の高い生活環境と個性的な生 活文化が求められるようになり, 各市町村は，それぞれ特色ある 地域社会を形成しながら, 快適 な町づくりや公園づくりを進め ることになった。

一方，台湾は都市化による開 発ラッシュが起き，市民が市街 地に打ける緑の量に対する要請 が表れ，自然を失いつつある都 市の内部に，森林を主体とした優れた自然環境が求められるよう になった。またモータリゼーションにより, 交通公園もこの時期 に整備された。

\section{（3）公園の質向上要求の時期（国民所得 10000 ドル以上期）}

この時期に, 日本では地域活性化拠点公園, 建設副産業等の有 効活用に資する公園などの施策が策定され, 台湾では, 社区総体 営造, 主題公園, 環境保護公園の施策が策定された。

都市公園の量が増加した後, 高所得社会に入り, 質の改善に対 する要請が出てきた。地域活性化や地域のアイデンティティが図 られるようになり, 地域の特色に活かした公園緑地の整備等が求 められるようになった。また近年の地球環境に対する関心が高ま り, 公園緑地は身近なレクリエーションの場から, 世界規模の環 境保全までをも担うことと意識されるようになった。

\section{表－4 台湾造園専門誌における諸外国の公園緑地事例数}

\begin{tabular}{|c|c|c|c|c|c|c|c|c|}
\hline \multicolumn{3}{|c|}{ 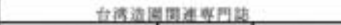 } & \multicolumn{6}{|c|}{ 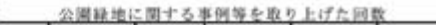 } \\
\hline 的名名 & I粪 & 出競年 & 且本 & $7 \times 11$ 办 & F1\% & $1+2 y x$ & $75: x$ & $z \omega$ th \\
\hline 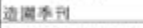 & vol, $1 \sim 13$ & $1985-1989$ & 12 & 12 & 0 & 1 & 1 & \\
\hline 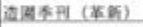 & vol, 1 -51 & 1990-2004 & 62 & 55 & 10 & 10 & s & 21 \\
\hline 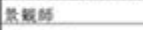 & vol. 1 $\sim 9$ & $1995-1998$ & 3 & 0 & 2 & 0 & 0 & 0 \\
\hline 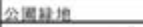 & volul $1 \sim 6$ & $2000-2003$ & 14 & 5 & 2 & 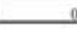 & 1 & \\
\hline & Hi & & 91 & 72 & 14 & 11 & $\theta$ & 28 \\
\hline
\end{tabular}

\section{5.まとめ}

本研究では，台湾の公園施策について，それに相当する日本の 施策公園を対置して考察した結果，以下のような結論を得た。

（1）台湾及び日本の公園は, 共通して量の拡充加質の向上へ と移行してきた。またそれは公園数の増加に見られるのみならず, 個別公園の規模も住区基幹公園から国営公園への拡大に見られる ように，大規模公園へと発展していった。

（2）公園の質は一般の公園設計から, 公園利用形態の多様化, 居住環境のアメニティ, 地域文化之産業之の連携による地域らし さが表れた公園，そして環境問題を意識した公園へと移行した。 つまり，公園への期待は，身近な生活環境から大きな社会環境の 範囲へと拡大していったと言える。

（3）台湾の施策公園は, 外国の先駆的事例を参考に整備が展開 し, 親水公園, 防災公園の整備など近隣国である日本の公園行政 は，常に，主要な参考之なっていると分析した。

（４）台湾之日本の施策公園の展開を比較した結果, 国民所得が 影響して，様々な公園施策がなされることが明確になった

（５）施策公園は, その国の国情に大きく影響を受けている。台 湾の環境保護公園は, 空気污染を改善するために樹種の指定があ ることが特徵であり, 台湾独自の施策であると言える。これは都 市公園が環境問題への対策として活用された例であると考えられ る。
（6）日本は高齢化が早く，いきいきふれあい公園（1985 年), 健康福祉公園都市づくり促進事業（1998 年）などがすでに推進 されてきた。しかし台湾には未だなく，近い将来，台湾もこのよ うな公園が現れると推測できる。

\section{引用文献}

1）日本公園緑地協会（1999）：公園緑地マニュアル平成 10 年度版：建設 省都市局, $126-156$

2 ) 㨬茂寿太郎・高梨雅明・後藤和夫（1990）：都市公園行政の現状之展 望：造園雑誌 53(3)，178-183

3 ）前掲書 1), 242

4) 台湾総督府（明治 32）：律令第 30 号：総督府報第 644 号

5 ）台湾総督府 $($ 昭和 12)：台湾都市計画講習録：同府

6 ）内政部（1975）：1975 年 5 月 29 日台内営字第 640675 号令発布（都市 計画定期通盤検討実施辦法)

7 ) 内政部営建署（1996）：営建政策白皮書：同署，321

8 ）台北駐日経済文化代表処：経済発展：ホームページ<http://www gio.gov.tw/taiwan-website/abroad/jp/fingertip >, 2004.1.03 参照

9 ）台北市政府工務局公園路灯工程管理処（2002）：台北市都市計画公園, 緑地, 児童遊楽場, 広場保留地及非都市計画公園参考資料：同府, $50 \mathrm{pp}$

10）台北市政府（1962）：台北市政紀要民国五十一年：同府，16-17

11) 李麗雪 (1989) : 由都市公園発展的観点探討台北市都市公園的演变： 国立台湾大学園芸研究所碩士論文, 51-56

12）中央日報：1974 年 3 月 29 日

13）宜蘭県政府（1992）: 宜蘭県長陳定南施政総報告彙編：同府，396

14）宜蘭県政府（1990）：冬山河風景区開発建設規劃報告：同府，191pp

15）前揭書 12), 113-114

16）蔡長啓（1991）：運動設施的規劃及流程簡介：国民体育季刊 vol.21(4), 4-9

17）韓鴻恩（2001）：運動公園用後評估之研究－以竹南運動公園為例：中 華大学碩士論文, 3-5

18）東京農業大学造園学科（1985）：造園用語辞典：彰国社，85

19）教育部 (1991)：運動公園規劃準則：同部, 9pp

20）陳貞蓉（2000）：台湾地区都会公園之発展：公園緑地季刊 vol.2, 16-19

21）行政院公共建設督導会報（1995）：公共建設報告書：行政院公共工程 委員会, $4-3-1$

22）謝平芳（1988）：台湾地区民衆参与都市公園規劃之研究-以花蓮市美嵛 山公園規劃為例：国立台湾大学土木工程学研究所碩士論文, 98

23）台北県政府（1994）：台北県社区参與公園規画報告書之一：同府，1-5

24）台北市政府（1996）：台北市政紀要民国八十五年：同府，3

25）台北市政府研究発展考核委員会（1997）：台北市政府各機関可開放市 民参與業務実施方案－八十五年十二月至八十六年五月辦理情形彙編： 同委員会

26）菅博嗣・前田文章（1997）：参加型公園づくりの全国事例概要：ラン ドスケープ研究 60(3)，234-241

27）台北州（昭和 7）：台北州告示第 54 号（台北市区計画变更）：台北州 報第 765 号

28）黄大洲（1997）：一座公園的誕生：中視文化出版社，298pp

29）前掲書 9$), 50 \mathrm{pp}$

30）（財）矢野恒太記念会（1992）：1992-93 世界国政図会：同会，453

31）台北市児童交通博物館：歴史沿革：ホームページ<http://kidspark com.tw $>: 2004.1 .10$ 参照

32）（財）矢野恒太記念会（1963）：日本国勢罒絵 1963 年版：同会，440

33）(財) 矢野恒太記念会（1995）：1995-96 世界国勢図絵：同会，447

34) 監察院 (2001) : 社区総体営造総体検調查報告書 : 遠流, 296pp

35）民生報：1994 年 12 月 10 日

36）台北市政府（1994）：台北市政紀要民国八十三年：同府，28-29

$37 ）$ 行政院環境保護署（2000）:空気品質保護 25 年紀実（1975 2000）:同 署, 97-121

38）主辦単位行政院環境保護署・中華民国景観学会（1996）：一般環保公 園学生競図実録：同主辦単位, 16-20

39）郭香哈（2001）：都市防災公園空間之建構之実践與省思：公園緑地季 刊 vol.3, 24-33

40）台北市政府工務局公園路灯工程管理処:防災公園：ホームペーシ < http://parklight.taipei.gov.tw/park02.htm> : 2004.10.19参照

41）経済企画庁（1977）：国民所得統計年報昭和 52 年版：大蔵省， 6

42）経済企画庁（1987）：国民経済計算年報昭和 62 年版：大蔵省，63

43）経済企画庁（1991）：国民経済計算年報平成 3 年版：大蔵省，53

44）経済企画庁（2003）: 国民経済計算年報平成 15 年版：大蔵省， 45

45）行政院主計処第三局：整体統計資料庫：ホームページ<http://www. dgbas.gov.tw/dgbas03/bs8/dbase/data.htm> : 2004.10.26 参照 